\title{
Inflation in Pakistan: Money or Wheat?
}

\author{
Mohsin S. Khan ${ }^{*}$ and Axel Schimmelpfennig ${ }^{* *}$
}

This paper examines the relative importance of monetary factors and structuralist supply-side factors for inflation in Pakistan. A stylized inflation model is specified that includes standard monetary variables (money supply, credit to the private sector), exchange rate, as well as wheat support price as a supply-side factor that has received considerable attention in Pakistan. The model is estimated for the period January 1998 to June 2005 on a monthly basis. The results indicate that monetary factors have played a dominant role in recent inflation, affecting inflation with a lag of about one year. Changes in the wheat support price influence inflation in the short run, but not in the long run. Furthermore, the wheat support price matters only over the medium term if accommodated by monetary policy.

\section{Introduction}

Understanding the factors that drive inflation is fundamental to designing monetary policy. Certainly in the long run, inflation is considered to be-as Friedman (1963) stated-always and everywhere a monetary phenomenon. However, other authors have pointed to supply-side developments in explaining inflation. This structuralist school of thought holds that supply constraints that drive up prices of specific goods can have wider repercussions on the overall price level. In Pakistan, increases in the wheat support price have been blamed for inflation. As such, the question "money or wheat" is not merely academic, but has profound implications for economic policy. If inflation is a monetary phenomenon, it is the responsibility of the central bank and the fiscal authorities to achieve price stability. If inflation is caused primarily by wheat support price increases, it would appear that the Ministry of Agriculture should play a key role in containing inflation.

\footnotetext{
* Mohsin S. Khan, Director, Middle East and Central Asia Department, International Monetary Fund, 700 19'Street, NW, Washington, D.C. 20431, USA, mkhan@imf.org

** Axel Schimmelpfennig , Economist, Middle East and Central Asia Department, International Monetary Fund, $70019^{\text {th }}$ Street, NW, Washington, D.C. 20431, USA, aschimmelpfennig@imf.org Disclaimer: The views expressed in this paper are those of the authors and should not be attributed to the International Monetary Fund, its Executive Board, or its management.
} 
After remaining relatively low for quite a long time, the inflation rate in Pakistan started to accelerate in late 2003. Following the 1998/99 crisis, inflation was reduced to below 5 percent by 2000 and remained stable through 2003. Tight monetary policy (combined with fiscal consolidation) appears to have contributed to this low inflation environment. ${ }^{1}$ Figure 1 shows that inflation follows broad money growth and private sector credit growth closely with a lag of about 12 months. With monetary growth picking up, inflation followed and increased sharply in late 2003, peaking at 11 percent year-on-year in April 2005. Average annual inflation appears to have stabilized around 8 to 9 percent by September 2005. The acceleration of inflation also coincided with two increases in the wheat support price in September 2003 and in September 2004 (Figure 2), which has reopened the debate whether wheat support price was driving inflation in Pakistan [Khan and Qasim (1996) and Sherani (2005)]. ${ }^{2}$

Figure 1. Inflation and Monetary Growth, 1999:1-2005:6

(Average annual growth in percent)

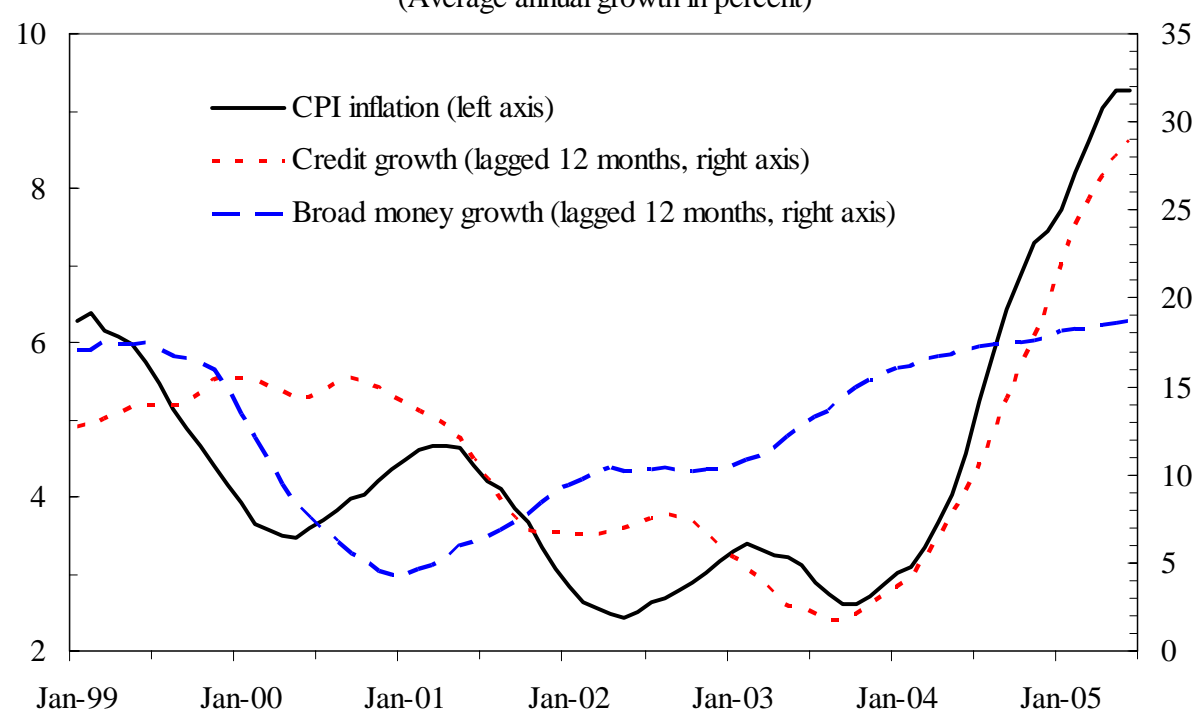

Source: National authorities; and Fund staff calculations.

\footnotetext{
${ }^{1}$ According to the State Bank of Pakistan (SBP) a change in the methodology of deriving the house rent index may also be partly responsible for the observed slowdown in headline inflation.

${ }^{2}$ The support price was raised again in September 2005.
} 
Figure 2. Inflation and Wheat Support Price, 1999:1-2005:6

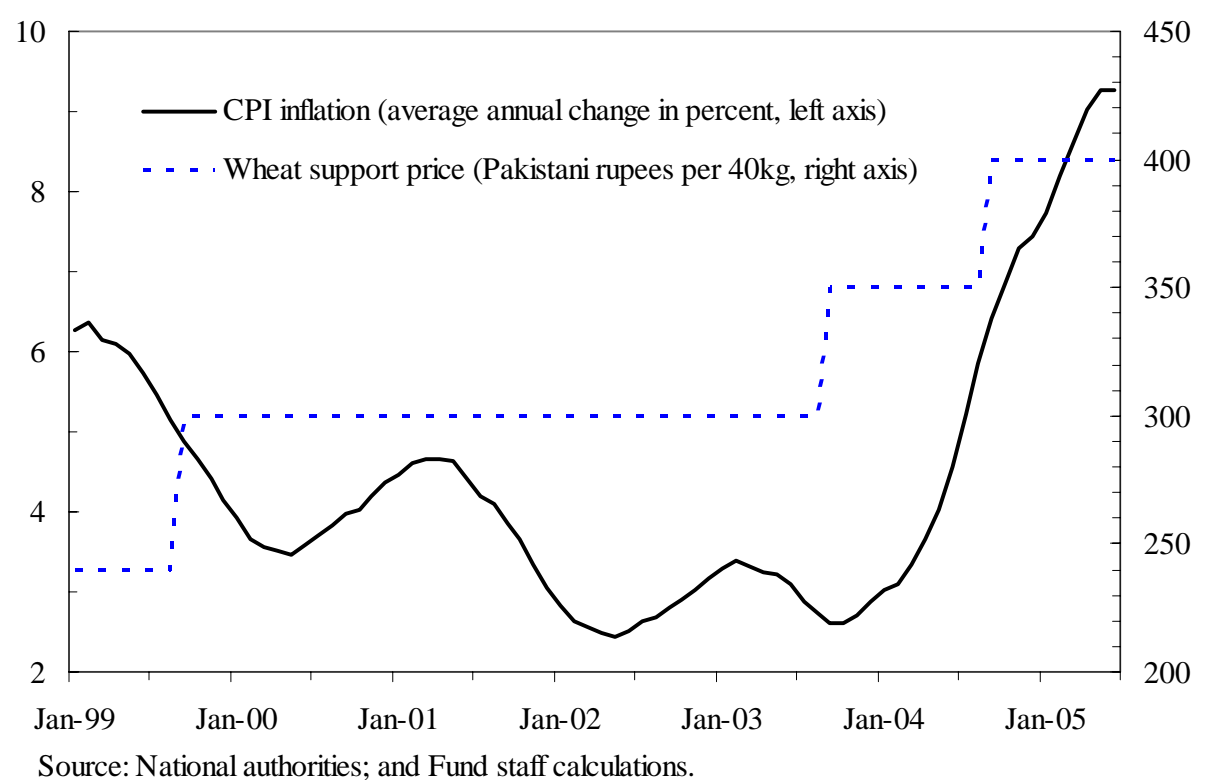

Wheat support price is the guaranteed minimum price at which the government will buy wheat. This price is set by the Ministry of Food, Agriculture and Livestock at the beginning of the harvest season in September. Actual procurement prices paid by the government can exceed the support price depending on market conditions. In Pakistan, the provinces and the Pakistan Agricultural Storage and Supplies Corporation (PASSCO) procure wheat and hold operational and strategic reserves to be in a position to stabilize the domestic wheat market in case of supply disruptions. In addition, the Trading Corporation of Pakistan (TCP) imports wheat to meet excess domestic demand. While wheat accounts for only 0.5 percent of the Consumer Price Index (CPI) basket, wheat and wheat-related products (flour) account for 5.1 percent of the CPI basket.

This paper finds that monetary factors are the main drivers of inflation in Pakistan, while wheat support price affects inflation in the short run. We specify a stylized inflation model that includes standard monetary variables (money supply, credit to the private sector), exchange rate, as well as wheat support price as a supply-side factor. The model is estimated with monthly data for the period January 1998 to June 2005. The results indicate that monetary factors have played a dominant role in recent inflation, affecting it with a lag of about one year. Increases in the wheat 
support price influence inflation in the short run. The wheat support price matters for inflation over the medium term only if accommodated by monetary policy.

The remainder of the paper is organized as follows. Section 2 reviews the relevant literature and introduces a stylized model to structure the analysis. Section 3 estimates the model and assesses the roles for explaining inflation played by monetary factors and the wheat support price. Section 4 briefly reviews the literature on the optimum level of inflation. Section 5 provides some conclusions.

\section{Basic Elements of the Model}

Structuralist models of inflation emphasize supply-side factors as determinants of inflation. They emerged in the 1950s as part of the structuralist theories of development promoted by Prebisch (see Bernanke 2005). ${ }^{3}$ In these models, inflation is driven by developments and bottlenecks on the real side of the economy. Food prices, administered prices, wages, and import prices are considered sources of inflation. For example, increasing food prices are considered to result from inelastic supply on account of concentrated land ownership. Structuralist models assume that such factors have to be accommodated by monetary policy-makers because they are determined outside the monetary sphere. Monetary developments in themselves are given little importance as independent determinants of inflation.

Several studies highlight the role of monetary factors for inflation in Pakistan, but also suggest a role for factors emphasized in structuralist models of inflation. Khan and Qasim (1996) find food inflation to be driven by money supply, valueadded in manufacturing and wheat support price. ${ }^{4}$ Non-food inflation is determined by money supply, real GDP, import prices and electricity prices. It is hardly surprising that changes in the wheat support price affect the food price index, given that wheat products account for 14 percent of the index. However, this does not automatically imply that headline inflation is affected by changes in the price of one particular item. Indeed, Khan and Qasim find that overall inflation is only determined by money supply, import prices, and real GDP. Sherani (2005), referring to their work, finds that increases in the wheat support price raise the CPI index (but not necessarily inflation). Sherani emphasizes that the high levels of inflation in 2005 largely resulted from a monetary overhang that was built up by loose monetary conditions. ${ }^{5}$ Regarding the role of the exchange rate, the size of a

\footnotetext{
${ }^{3}$ The two most well-known papers are Noyola (1956) and Sunkel (1958).

${ }^{4}$ The authors also provide a concise survey of earlier studies for Pakistan with similar findings.

${ }^{5}$ Studies for other countries also find some evidence of structuralist factors as a source of inflation. Mohanty and Klau (2001) find that food and energy prices as well as administered prices have an
} 
potential exchange rate pass-through is unclear. Choudhri and Khan (2002) do not find evidence of exchange rate pass-through in a small VAR, while Hyder and Shah (2004) find some evidence of exchange rate pass-through in a larger VAR. Bokil and Schimmelpfennig (2005) find broad money and private sector credit growth to be good leading indicators for inflation.

We start our stylized model from a monetarist perspective. Agents hold money for transaction purposes, as a store of value, and for speculative purposes. For a constant velocity $(v)$, inflation $(\dot{p})$ results if money growth $(\dot{m})$ exceeds real GDP growth $(\dot{y})$. The opportunity cost of holding money, i.e. the interest rate $r$, reduces money demand and thus inflation. Moreover, financial deepening and innovations enable agents to use alternative monetary instruments in lieu of cash. Thus, the velocity of a particular monetary aggregate, say M2, changes if agents switch from cash or demand deposits to instruments included only in M3. In an open economy headline inflation can also be affected by movements of the exchange rate $(e) .{ }^{6}$ The general open-economy monetary model is then given by

$$
\dot{p}=f(\dot{m}, \dot{y}, \dot{v}, r, \dot{e})
$$

where lower case letters denote the natural logarithm of a variable and a dot over a variable denotes the first derivative with respect to time.

To this, we add the wheat support price $(w)$ to arrive at our stylized hybrid "monetarist-structuralist" model:

$$
\dot{p}=f(\dot{m}, \dot{y}, \dot{v}, r, \dot{e}, \dot{w})
$$

For non-stationary time series, Equation (2) only reflects short-run relationships as the variables are in first differences and do not include a co-integrating relationship. However, the aspects of the model that reflect monetarist thinking will tend to be long-run relationships. The wheat support price can either have only a short-run impact on inflation, or also a long-run impact on the price level (but not inflation). The model can easily be re-written in levels and in an error

\footnotetext{
impact on inflation if accommodated by monetary policy in a group of 14 emerging market countries. Domaç (2004) finds administered prices to influence Turkish inflation in some specifications. An earlier study for Bangladesh [Taslim (1982)] concludes that structuralist factors (largely agricultural bottlenecks) contribute to inflation, but that monetary factors seem dominant.

${ }^{6}$ Import prices could also play a role, in particular if the exchange rate is pegged. Unfortunately, import prices are not available at a monthly frequency, but since Pakistan had a flexible exchange rate regime during our sample period, import prices should be less important than in previous years.
} 
correction representation to differentiate between short-run and long-run relationships.

\section{Empirical Results}

We estimate the stylized model in growth rates as well as in log levels. Since our sample extends over a crisis period and subsequent wide-ranging economic reforms as well as a growth take-off, it may be difficult to discern long-run relationships from the data due to structural changes and non-constant parameters. However, we would still expect short-run relationships to reflect our proposed model structure. Therefore, as a first step, we estimate Equation (2) to gain an understanding of some basic relationships and short-run dynamics. ${ }^{7}$ In the second step, we estimate the model as a vector error correction model (VECM) in loglevels to investigate whether we can find a co-integrating vector that would provide information about long-run behavior. ${ }^{8}$

\subsection{Data and Sample}

Our database covers the period January 1998 to June 2005 on a monthly basis. The choice of sample reflects a trade-off between having sufficient observations and avoiding structural breaks that would complicate the empirical analysis. Banking sector reforms were initiated in 1997 and pursued vigorously after 1999, leading to increased intermediation. Financial deepening also occurred as confidence returned in the aftermath of the 1998/99 crisis and with the new government restoring macroeconomic stability. Taken together, this implies that the monetary transmission mechanism has evolved and money demand has possibly shifted over the sample period which may lead to non-constant parameters, in particular with respect to long-run parameters.

Reflecting our stylized model and data availability, the database includes:

- CPI: overall consumer price index-the percentage change of which is also termed "headline inflation".

- Monetary variables: broad money; private sector credit; and 6-month treasury bill (T-bill) rate (SBP’s key policy rate).

\footnotetext{
${ }^{7}$ Note that this model may be misspecified if we have non-stationary data and there exists a cointegrating vector.

${ }^{8}$ Alternatively, one could estimate a structural VAR to arrive at an inflation forecast that can be linked to monetary policy instruments. This would be an interesting area of research to support monetary policy formulation.
} 
- Activity variables: interpolated real and nominal GDP (12-month moving average of the fiscal year GDP data) ${ }^{9}$ and large-scale manufacturing index (LSM).

- Exchange rate: nominal effective exchange rate (NEER).

- Wheat support price: guaranteed minimum government purchase price.

The basic correlations between the variables are shown in Table 1.

The log levels of all variables are non-stationary. Most variables are integrated of order one (Table 2). However, somewhat surprisingly, our interpolated real and nominal GDP series are integrated of order two. This would suggest that our GDP series cannot be part of a long-run cointegrating relationship with other variables that are only integrated of order one. Alternatively, the LSM may be a meaningful proxy for the activity variable. ${ }^{10}$

Data for Pakistan is subject to overlapping seasonality stemming from Gregorian calendar effects (including agricultural seasonality) and Islamic calendar effects. Riazuddin and Khan (2002) construct variables to address Islamic seasonality. For regressions based on growth rates, we control for seasonality by using 12-month moving averages. Bokil and Schimmelpfennig (2005) show that this is sufficient to take account of both sources of seasonality. The approach has the advantage of requiring no additional regressors. However, for regressions based on log levels, we include monthly dummies and the Islamic calendar control variables from Riazuddin and Khan (2002). ${ }^{11}$

\subsection{CPI Inflation}

First, we analyze the impact of changes in the wheat support price on headline inflation. We estimate two variants of our stylized model using either broad money or private sector credit to capture the impact of monetary policy. The models are estimated using the PcGets routine in PcGive which automatically tests down a general model. ${ }^{12}$ In our case, we include 12 lags of all variables in the general model. In principle, the resulting specific model can then include

\footnotetext{
${ }^{9}$ GDP data is available only at annual frequency.

${ }^{10}$ The correlation coefficient between the annual LSM index and annual real GDP is 0.97 which suggests that a 12-month moving average of the LSM index is probably a reasonable proxy for monthly real GDP.

${ }^{11}$ We thank R. Riazuddin and M. Khan for kindly providing their data to us. In some specifications, the control variables for calendar effects can be dropped.

12 The routine is described and illustrated in Hendry and Krolzig (2004).
} 
individual lags of the variables from the general model, or exclude variables altogether.

We focus on summary coefficients that give the direction of influence of a particular regressor after all dynamics have played out. The estimated specification is an autoregressive distributed lag model (ADL):

$A(L) \dot{p}_{t}=B(L) \dot{x}_{t}+u_{t}$,

where $x$ is the vector of independent variables that includes inter alia the wheat support price. $A(L)$ and $B(L)$ are lag polynomials that take the form:

$$
A(L) \dot{p}_{t}=1-\sum_{i=1}^{12} A_{i} \dot{p}_{t-i} \quad \text { and } \quad B(L) \dot{x}_{t}=\sum_{j=0}^{12} B_{j} \dot{x}_{t-j} \text {. }
$$

ADL can be re-written as:

$\dot{p}_{t}=\frac{B(L)}{A(L)} \dot{x}_{t}+\varepsilon_{t}$

The coefficient $\beta$ that describes the impact of changes in the independent variables on inflation after all dynamics have played out is then given by:

$\beta=\frac{B(1)}{A(1)}$

The empirical results are broadly consistent with our stylized model. Models M1 and M2 in Table 3 are based on the general specification in Equation (2). In M1, we use broad money, and in M2, we use private sector credit to measure monetary policy. In both cases, no regressor is completely dropped from the model. PcGets only eliminates some individual lags. However, in M1, the T-bill rate, and in M2, the NEER, the T-bill rate, and the wheat support price carry the wrong sign. We therefore drop these regressors (except for the wheat support price) to arrive at our two preferred specifications M3 and M4. M3 explains CPI inflation as a function of broad money growth, real GDP growth, NEER appreciation, and the average annual wheat support price change. M4 explains CPI inflation as a function of private sector credit growth, real GDP growth, and the average annual wheat support price change. These results illustrate that monetary factors and the wheat 
support price are determinants of inflation, at least in the short run. Likewise, real GDP growth matters, and to some extent, there is an impact from NEER appreciation. ${ }^{13}$ Monetary growth affects inflation with a lag of around 12 months. ${ }^{14}$

\subsection{A Vector-Error Correction Model}

Based on the above results, we specify a VECM to identify long-run relationships between our variables. To limit the size of the VECM, we start with the preferred specifications M3 for a VECM including broad money and M4 for a VECM including private sector credit. We find that a meaningful cointegrating relationship exists only in the case of a VECM including private sector credit.

\section{CPI, private sector credit, and wheat support price VECM}

The preferred VECM contains the CPI, private sector credit, and the wheat support price. We estimate the system with monthly dummies and Islamic calendar effect controls provided by Riazuddin and Khan (2002). ${ }^{15}$ Based on the stylized model and the results for the inflation equation above, we initially estimate a system including the CPI (cpi), private sector credit (credit), real GDP, and the wheat support price (wheat). However, no meaningful cointegrating relationship is found in this system, and we estimate a reduced system without real GDP. ${ }^{16}$ This reduced system has a cointegrating rank of one (Table 5). The cointegrating vector is given by:

$$
\text { cpi }=1.733+0.205 * \text { credit }+0.004 * \text { wheat }+0.002 * \text { trend }
$$

The t-statistics in parentheses suggests that wheat support price is not part of the long-run relationship. We can also drop the seasonal controls which give us additional degrees of freedom. This yields:

\footnotetext{
${ }^{13}$ As a robustness test, we repeated this exercise using a dummy for months in which the wheat support price was increased. Unlike the average annual change in the wheat support price, this dummy is not retained by $P c G e t s$. The results are available from the authors upon request.

${ }^{14} \mathrm{M} 3$ includes a 7 and a 11 month lag of broad money growth. M4 includes 1, 3, 5, 10, and 12 month lags for private sector credit growth.

${ }^{15}$ The lag length is set at 6 . Table 4 shows information criteria for different specifications and lag lengths.

${ }_{16}$ This finding could reflect that real GDP may be integrated of order two while all other variables are integrated of order one. However, using the LSM instead of real GDP does not alter the result.
} 
cpi $=0.994+\begin{array}{ll}0.263 * \text { credit } \\ (9.803)\end{array}+0.001 *$ trend

Based on these results, wheat price does not affect CPI in the long run, but only in the short run; by design, the VECM contains lags of the first difference of all variables in the system in each equation. Monetary conditions, as measured by private sector credit, affect CPI in the long and short run.

The co-integrating vector describes recent inflation developments well. Starting in early 2003, monetary conditions were very accommodating, private sector credit growth picked up, and disequilibrium in the CPI-private sector credit relationship emerged (Figure 3). As inflation also picked up, disequilibrium has been reduced, but not yet been eliminated through June 2005. The loading coefficient in the equation for CPI indicates that 23 percent of a deviation from the long-run relationship is adjusted in the next period.

Figure 3. The Cointegrating Vector-CPI and Private Sector Credit

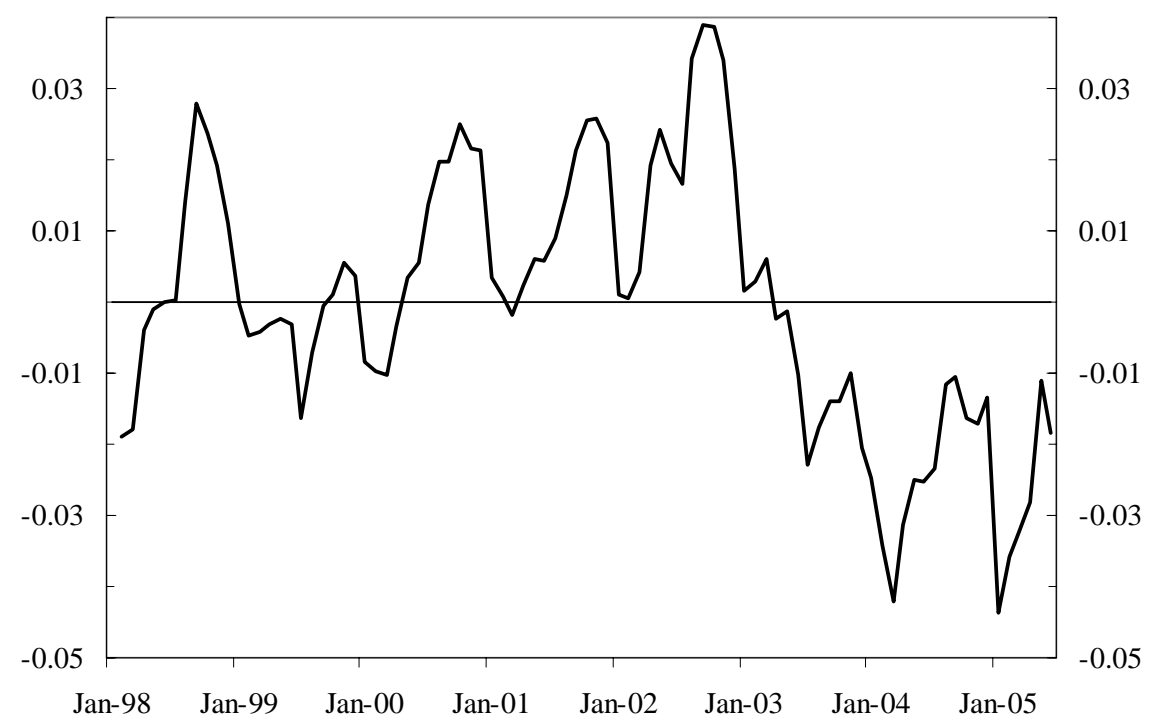

Source: National authorities; and Fund staff calculations. 
Figure 4. Impulse Response Function for CPI Based on the CPI, Private Sector Credit, Wheat Support Price VECM 1/

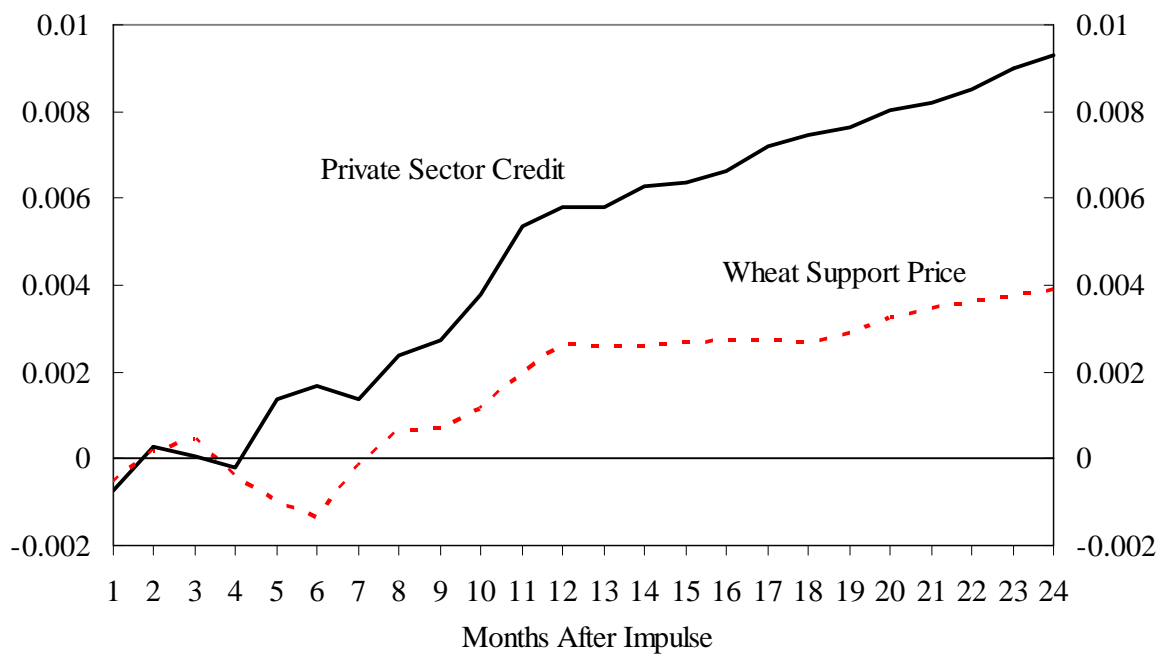

Source: National authorities; and Fund staff calculations.

1/ Generalized 1 standard deviation impulse.

The CPI increases after shocks in the private sector credit or the wheat support price equation. We calculate impulse response functions based on generalized 1standard deviation impulses [Pesaran and Shin (1998)]. In response to an innovation in private sector credit or the wheat support price, CPI initially falls (akin to the price puzzle), but then increases after 2-4 months (Figure 4 ) ${ }^{17}$ The impact of an impulse to private sector credit is more pronounced than the impact of an impulse to the wheat support price.

\section{CPI, broad money, and wheat support price}

No meaningful VECM that contains broad money could be identified in the sample. Based on the stylized model and the findings in the inflation regressions above, we started with a system including CPI, broad money, NEER, real GDP, and the wheat support price. ${ }^{18}$ The system also included controls for Gregorian

\footnotetext{
17 The price puzzle is a fairly common empirical finding where an unexpected tightening of monetary policy initially leads to an increase rather than a decrease in the price level. This theoretical inconsistency can be addressed by introducing forward-looking variables [e.g. Brissimiss and Magginas (2004) and Balke and Emery (1994)].

${ }^{18}$ Alternatively, we used the LSM instead of real GDP, but this did not change the results.
} 
and Islamic calendar effects and in some specifications deterministic components. We set the lag length to 6 to maintain sufficient degrees of freedom; the optimum lag length for this system is 12 , but our sample is not large enough to allow this number of parameters (Table 4). We experimented with different specifications for the deterministic component, and dropped or retained any of the endogenous variables. Nonetheless, no cointegrating relationship emerged that would be broadly consistent with our model or would yield sensible impulse response functions.

The failure to find cointegration most likely stems from ongoing changes to fundamental relationships, in particular money demand, during the sample. Bokil and Schimmelpfennig (2005) show that a money demand equation for Pakistan suffers from non-constant coefficients when estimated with either annual or monthly data. For annual data, recursive coefficient estimates diverge significantly after 1998 from the coefficient estimated in the 1978-2004 sample. With monthly data, the recursive coefficients fluctuate throughout the 1995-2004 sample, in the case of real GDP even switching signs. These findings are likely to reflect the impact of the 1998/99 debt crisis on the Pakistani economy and the reforms that followed. Macroeconomic stabilization and financial sector reforms, can be expected to have affected estimated parameters. Moreover, De Grauwe and Polan (2005) show that standard quantity theory of money relationships are hard to identify in countries with inflation of less than 10 percent.

\subsection{A Graphical Analysis}

A simple graphical analysis can be used to further analyze the role of monetary factors and structuralist factors. In our sample, there are three episodes of wheat support price increases: September 1999, September 2003, and September 2004. Figure 5 contrasts the behavior of some key variables in the 12 months after these three increases. Broad money and credit growth are lagged by 12 months to allow for the temporal structure of the monetary transmission mechanism.

The graphical analysis emphasizes the key role played by monetary factors. The main difference between the three episodes of wheat support price increases is the 
Figure 5. Inflation and Monetary Developments after Wheat Support Price Increases 1/ (Average annual change in percent)

(a) CPI

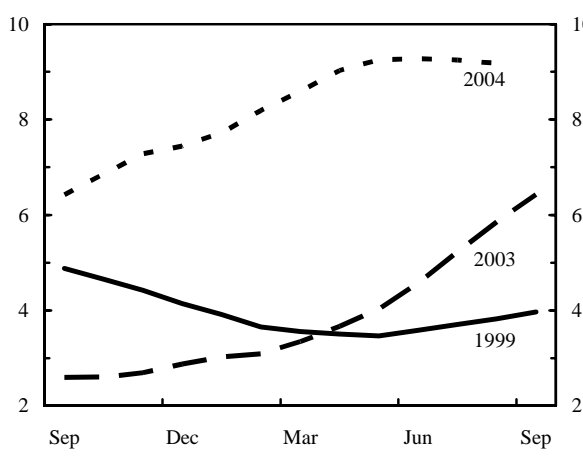

(c) Broad Money (lagged 12 months)

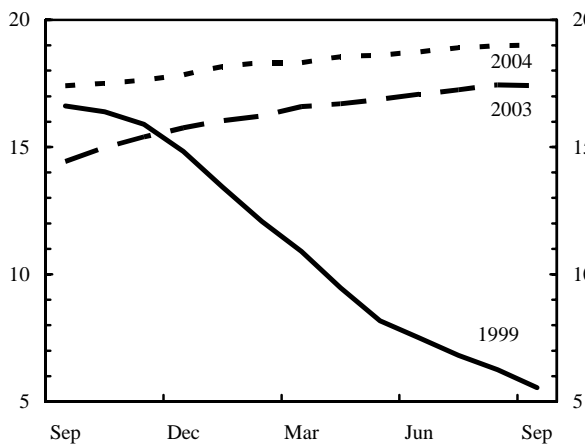

(e) Private Sector Credit (lagged 12 months)

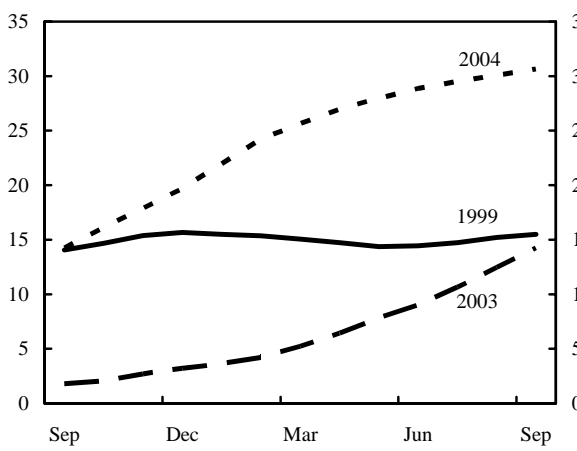

(b) Food Price Index

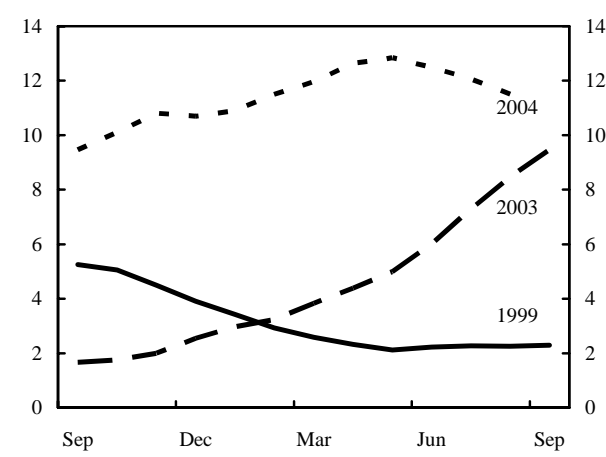

(d) Nonfood Price Index

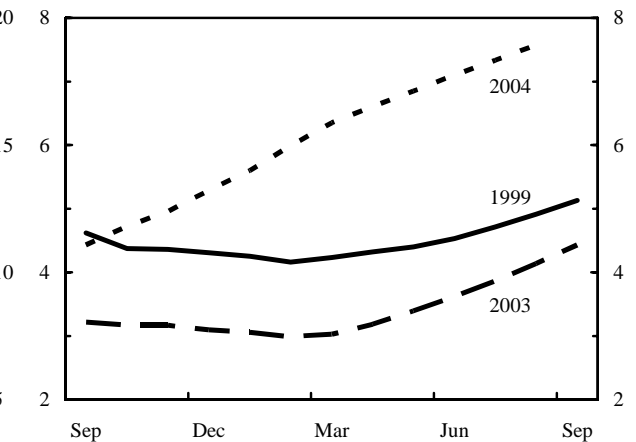

(f) Nonfood, Non-energy Price Index

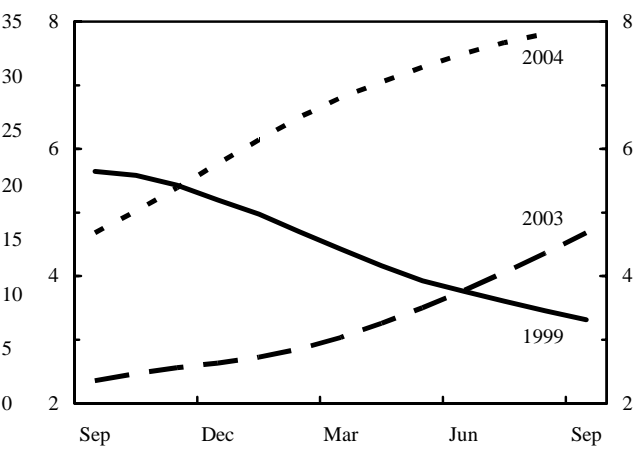

Source: Pakistani authorities; IMF, International Financial Statistics; and Fund staff calculations.

1/ The figure depicts developments in the 12 months after the wheat support price increases in September 1999, September 2003, and September 2004. 
monetary condition. ${ }^{19}$ Following the 1999 increase, monetary growth was subdued, and inflation remained low. The slight increase in headline inflation in mid-2000 stemmed from nonfood inflation rather than food inflation, suggesting that the wheat support price played little role in explaining headline inflation. In contrast, monetary growth was high and accelerating at the time of the 2003 and 2004 wheat support price increases. This triggered acceleration in nonfood inflation. Food inflation accelerated even more which could reflect the additional impact of the increased wheat support price. With accommodating monetary conditions, there may have been second-round effects from food to nonfood inflation.

Domestic wheat prices may have been influenced more by world prices than by the support price. Figure 6 show that domestic wheat prices follow international prices, though sometimes with a lag. The pronounced domestic wheat price increase after May 2003 started before the wheat support price was raised, and after a prolonged period in which international prices had been growing faster than domestic prices. As such, domestic wheat prices would most likely have risen even in the absence of an increase in the wheat support price.

Figure 6. Wheat Price Indices, 1998:1-2005:6

$(1998: 1=100)$

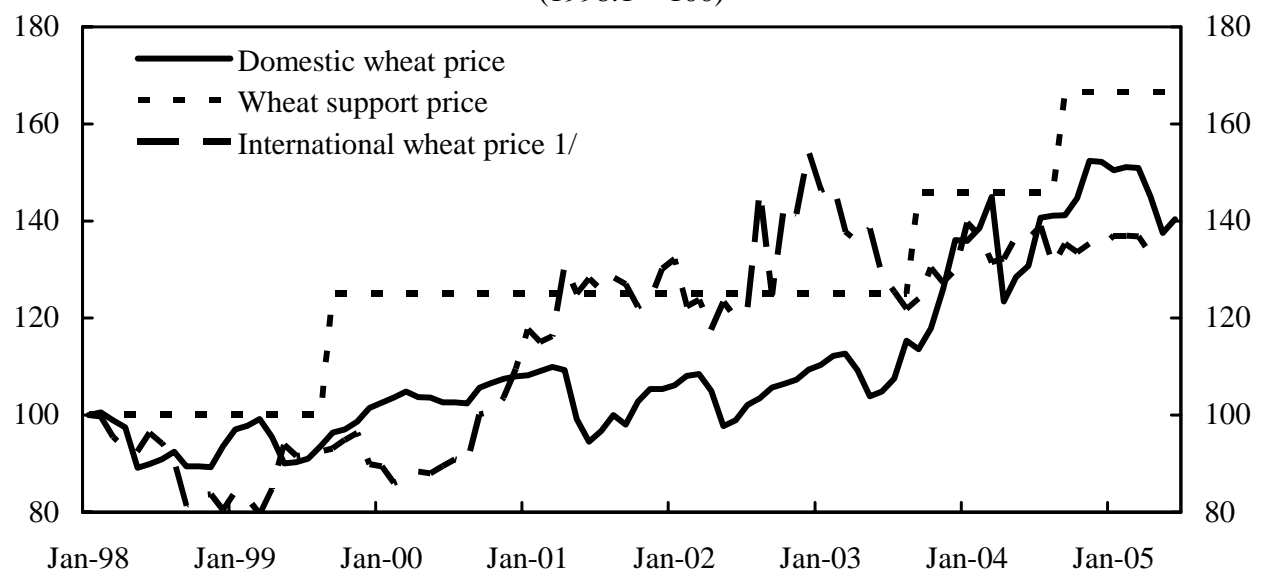

Source: Pakistani authorities; IMF, International Financial Statistics; and Fund staff calculations.

1/ International price of Australian wheat, coverted to Pakistani rupees.

\footnotetext{
${ }^{19}$ Another difference is that the private sector was allowed to enter the wheat market for the first time in 2003. Some observers have commented that speculative buying and 'hoarding' contributed to rising wheat prices. However, this was greatly facilitated by the availability of cheap credit and also reflected that, in fact, international wheat prices were much higher than domestic prices (Figure 6).
} 


\section{Why Worry About Inflation?}

High and persistent inflation is a regressive tax adversely impacting the poor and economic prospects. The poor hold few real assets or equity, and their savings are typically in the form of cash or low-interest bearing deposits; this group is most vulnerable to inflation as it erodes savings. Moreover, high and volatile inflation has been found to be detrimental to growth and financial sector development. High inflation obscures the role of relative price changes thus inhibiting optimal resource allocation.

Inflation hurts growth once it exceeds a certain threshold. A number of empirical studies have established that the relationship between inflation and growth is nonlinear. At low levels of inflation, inflation has either no impact or a positive impact on growth. However, once inflation exceeds a certain threshold, it has an adverse impact on long-run growth. In a panel of 140 countries, Khan and Senhadji (2001) estimate this threshold to be 1-3 percent for industrial countries and 7-11 percent in developing countries. ${ }^{20}$ Focusing on Middle East and Central Asian countries including Pakistan, Khan (2005) estimates the optimum inflation rate to be 3 percent and argues that policy-makers should keep inflation below 6 percent to avoid a negative impact on growth. Mubarik (2005) revisits the threshold question using exclusively time-series data for Pakistan from 1973 to $2000 .{ }^{21}$ He finds that inflation in excess of 9 percent harms short-run growth in Pakistan. Another recent study for Pakistan by Hussain (2005) estimates a threshold of 4-6 percent beyond which inflation harms growth.

High inflation also inhibits financial development. Financial market institutions are intermediaries that reduce frictions between savers and investors (including adverse selection, moral hazard, or conflicting time preferences). Inflation makes this intermediation more costly because inflation tax lowers long-run real returns. As a result, credit is rationed and financial depth is reduced. As in the case of growth, there appears to be a threshold beyond which inflation adversely affects financial sector developments, while there are no negative effects at low levels of inflation. Khan, Senhadji, and Smith (2005) estimate this threshold to be about 36 percent in a panel of 168 countries. The adverse effect of inflation on financial development is one mechanism by which inflation can hurt growth. For example, Loayza and Ranciere (2005) find a positive long-run relationship between financial development and growth in a sample of 75 countries.

\footnotetext{
${ }^{20}$ The authors also provide an extensive survey of the relevant literature.

21 The author uses the Hodrick-Prescott filter to reduce volatility in the data which potentially removes relevant information. Furthermore, in a single country case, the threshold will be restricted to be within the range of inflation experienced by that country.
} 
In Pakistan, periods of low inflation are associated with high growth rates and vice versa. Figure 7 shows real per capita growth and CPI inflation. Between 1978 and 1991, inflation was 8 percent on average and real per capita growth averaged 3 percent. Between 1992 and 1997, inflation increased on average to 11 percent, while real per capita growth fell substantially and averaged only 1 percent. Finally, between 1998, inflation was reduced again to an average of 5 percent, and real per capita growth displayed a dramatic recovery. Of course, there are other factors that determine growth in the short-run and in the long-run [e.g. van Rooden (2005)]. Nonetheless, Pakistan's growth performance has been best when inflation was contained to 8 percent or lower.

For Pakistan, the direct inflation-growth nexus suggests a threshold of 4-6 or 9 percent, while the inflation-financial development nexus suggests a lower threshold of 3-6 percent. Given that actual inflation will fluctuate around an inflation target, it is prudent to set the target sufficiently low to ensure that actual inflation does not enter the double-digit range. Taken together, SBP's inflation target of 5 percent is, therefore, appropriate. ${ }^{22}$

Figure 7. Real Per-Capita Growth and CPI Inflation, 1975-2004

(3-year moving averages, in percent)

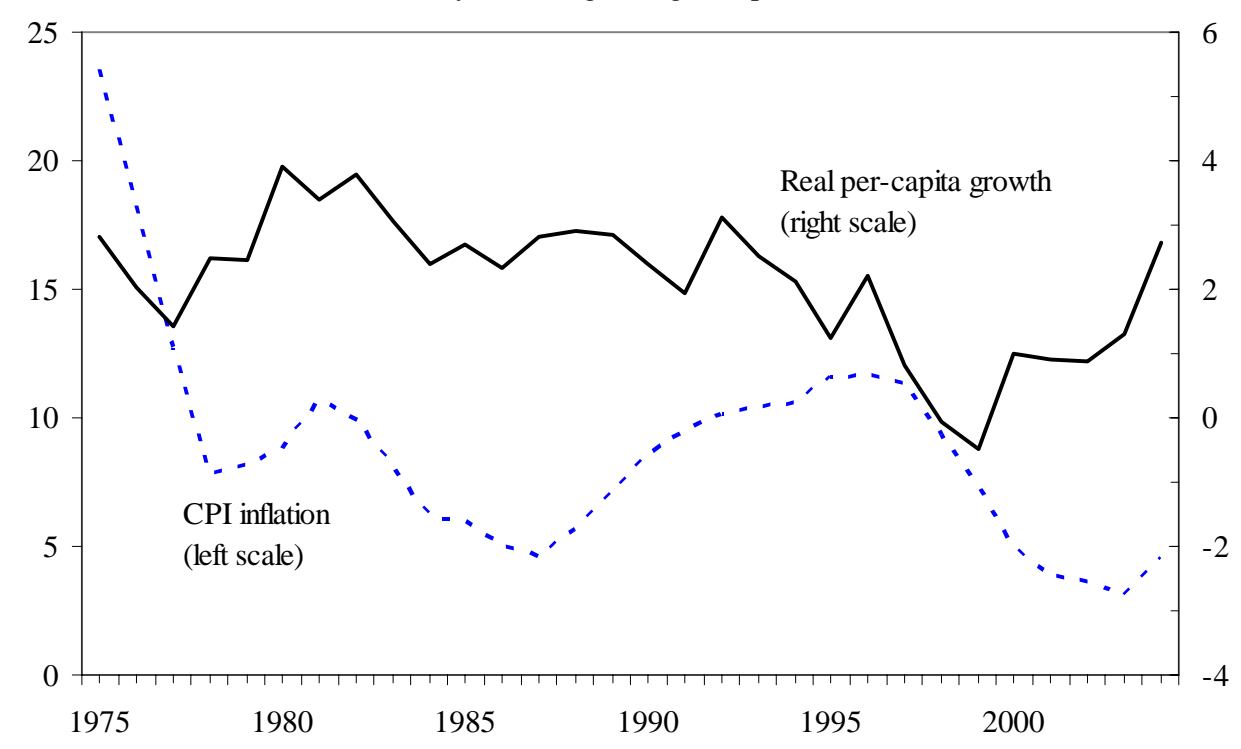

Source: IMF, International Financial Statistics ; and Fund staff calculations.

${ }^{22}$ Annual inflation targets can vary depending on where inflation stands at the beginning. 


\section{Summary and Conclusions}

The empirical results presented in this paper show that monetary factors determine inflation in Pakistan. Broad money growth and private sector credit growth are the key variables that explain inflation developments with a lag of around 12 months. A long-run relationship exists between the CPI and private sector credit. The wheat support price affects inflation in the short run, but not in the long run. The answer to the question "money or wheat?" is "money!"

Pakistan's growth record since the 1970s underscores that high and persistent inflation is harmful to growth. Periods of high inflation have coincided with low growth spells, while high growth episodes tend to be associated with a low inflation environment. In light of the empirical thresholds beyond which inflation harms growth and financial development, an appropriate inflation target for Pakistan is 5 percent.

The overarching objective of the SBP should, therefore, be price stability. The SBP should first and foremost focus its attention and policies to keep inflation close to its target of 5 percent. In principle, the SBP could also target an exchange rate level as a nominal anchor to achieve macroeconomic stability. However, this implies adopting the anchor country's monetary policy and may yield a suboptimal rate of inflation. In addition, the exchange rate would no longer be available to offset the impact of external shocks on the domestic economy. The SBP is fully capable of implementing its own independent monetary policy consistent with the needs of the domestic economy. Maintaining price stability will ultimately be the best policy contribution to sustained growth that the SBP can make. While there may not be a trade-off between inflation and growth in the short run, it certainly exists in the medium and long run.

Price stability can be approximated by different metrics. While headline inflation is better understood by the public, it is often argued that monetary policy should be more concerned with core inflation. Given the volatility of some components of the CPI, in particular food prices and energy prices, core inflation (approximated as nonfood, non-energy or the SBP's trimmed mean definition) is a better measure of underlying inflation trends than headline inflation. Nonetheless, headline inflation is better understood by the public and affects households immediately. Taken together, core inflation is the right target for monetary policy, in particular over the medium term, but the SBP also needs to keep a watchful eye on headline inflation. 
Finally, monetary policy has to be forward-looking to achieve its inflation target. Current monetary conditions affect inflation with a lag of around 12 months in Pakistan. There seems to be a fairly stable relationship between private sector credit growth and inflation 12 months from now. In addition, there is also a relationship between broad money growth and inflation 12 months from now. Therefore, the SBP should set monetary policy today with a view to meeting its inflation target around one year from now.

\section{References}

Balke, N., and K. Emery (1994). “Understanding the Price Puzzle.” Economic and Financial Policy Review (Fourth Quarter), Federal Reserve Bank of Dallas.

Bernanke, Ben S. (2005). "Inflation in Latin America-A New Era?” Remarks, Stanford Institute for Economic Policy Research Economic Summit, Feb. 11. http://www.federalreserve.gov/boarddocs/speeches/2005/20050211/default.ht m.

Bokil, M. and A. Schimmelpfennig (2005). "Three Attempts at Inflation Forecasting in Pakistan.” IMF Working Paper No. 05/105. Washington, D.C.: IMF.

Brissmiss, S. and N. Magginas (2004). Forward-Looking Information in VAR Models and the Price Puzzle. Working Paper No. 10. Athens: Bank of Greece.

Choudhri, E. and M. Khan (2002). "The Exchange Rate and Consumer Prices in Pakistan: Is Rupee Devaluation Inflationary?” Pakistan Development Review, 41: 107-20.

Domaç, I. (2004). Explaining and Forecasting Inflation in Turkey. Policy Research Working Paper 3287. Washington, D.C.: World Bank.

De Grauwe, P. and M. Polan (2005). "Is Inflation Always and Everywhere a Monetary Phenomenon?,” Scandinavian Journal of Economics, 107: 239-259.

Friedman, M. (1963). Inflation: Causes and Consequences, NY: Asia Publishing House.

Hendry, D. and H. Krolzig (2004). We Ran One Regression. Oxford: Oxford University. http://www.nuff.ox.ac.uk/economics/papers/2004/w17/OneReg.pdf.

Hyder, Z. and S. Shah (2004). "Exchange Rate Pass-Through to Domestic Prices in Pakistan.” SBP Working Paper No. 5. Karachi: State Bank of Pakistan.

Hussain, M. (2005). "Inflation and Growth: Estimation of Threshold Point for Pakistan.” Pakistan Business Review, October.

Khan, A. and M. Qasim (1996). "Inflation in Pakistan Revisited." Pakistan Development Review, 35, 4, Part II: 747-759. 
Khan, M. (2005). Inflation and Growth in MCD Countries. Unpublished Manuscript. Washington, D.C.: IMF.

Khan, M. and A. Senhadji (2001). "Threshold Effects in the Relationship between Inflation and Growth.” IMF Staff Papers, 48: 1-21.

Khan, M., A. Senhadji, and B. Smith (2005). "Inflation and Financial Depth.” Macroeconomic Dynamics. Forthcoming.

Loayza, N. and R. Ranciere (2005). "Financial Development, Financial Fragility, and Growth.” IMF Working Paper No. 05/170. Washington, D.C.: IMF.

MacKinnon, J. (1996). "Numerical Distribution Functions for United Root and Cointegration Tests.” Journal of Applied Econometrics, 11: 601-18.

MacKinnon, J., A. Haug, and L. Michelis (1999). "Numerical Distribution Functions of Likelihood Ratio Tests for Cointegration.” Journal of Applied Econometrics, 14: 563-77.

Mohanty, M. and M. Klau (2001). "What Determines Inflation in Emerging Market Economies?” Working Papers No. 8. Basel: BIS.

Mubarik, Y. (2005). "Inflation and Growth: An Estimate of the Threshold Level of Inflation in Pakistan.” SBP-Research Bulletin, 1: 35-44.

Noyola, J. (1956). "El Desarrollo Económico y la Inflación en México y otros Países Latinoamericanos.” Investigación Económica, XVI, 4.

Pesaran, H. and Y. Shin (1998). "Generalized Impulse Response Analysis in Linear Multivariate Models.” Economics Letters, 58: 17-29.

Riazuddin, R. and M. Khan (2005). "Detection and Forecasting of Islamic Calendar Effects in Time Series Data.” SBP-Research Bulletin, 1: 25-34.

Sherani, S. (2005). "The Dark Side of the Force.” ABN-AMRO Economic Focus - Pakistan. (Monday, May 30).

Sunkel, O. (1958). "Inflation in Chile: An Unorthodox Approach." International Economic Papers, No. 10, 1960.

Taslim, M. (1982). "Inflation in Bangladesh: A Reexamination of the Structuralist- Monetarist Controversy.” Bangladesh Development Studies, 10: 23-52.

van Rooden, R. (2005). “Is Pakistan's Growth Acceleration Sustainable?” International Monetary Fund, Pakistan-Selected Issues and Statistical Appendix, IMF Country Report No. 05/408. Washington, D.C.: IMF. 


\section{Appendix. Tables}

Table 1. Correlation Between Main Variables in Log Levels (Sample: January 1998 to June 2005)

\begin{tabular}{lrrrrrrrr}
\hline & CPI & $\begin{array}{c}\text { Broad } \\
\text { money }\end{array}$ & $\begin{array}{c}\text { Private } \\
\text { sector } \\
\text { credit }\end{array}$ & Real GDP & $\begin{array}{c}\text { LSM } \\
\text { index }\end{array}$ & $\begin{array}{c}\text { 6-month t- } \\
\text { bill }\end{array}$ & NEER & $\begin{array}{c}\text { Wheat } \\
\text { support } \\
\text { price }\end{array}$ \\
\hline CPI & 1.00 & 0.98 & 0.97 & 0.99 & 0.96 & -0.67 & -0.95 & 0.94 \\
Broad money & 0.98 & 1.00 & 0.97 & 0.99 & 0.98 & -0.76 & -0.91 & 0.89 \\
Private sector credit & 0.97 & 0.97 & 1.00 & 0.98 & 0.98 & -0.65 & -0.91 & 0.92 \\
Real GDP & 0.99 & 0.99 & 0.98 & 1.00 & 0.98 & -0.73 & -0.94 & 0.93 \\
LSM index & 0.96 & 0.98 & 0.98 & 0.98 & 1.00 & -0.67 & -0.90 & 0.89 \\
6-month t-bill & -0.67 & -0.76 & -0.65 & -0.73 & -0.67 & 1.00 & 0.67 & -0.60 \\
NEER & -0.95 & -0.91 & -0.91 & -0.94 & -0.90 & 0.67 & 1.00 & -0.88 \\
Wheat support price & 0.94 & 0.89 & 0.92 & 0.93 & 0.89 & -0.60 & -0.88 & 1.00 \\
\hline
\end{tabular}

Source: National authorities; Fund staff calculations.

Table 2. Test for Non-Stationarity of Variables in Log-Levels (Sample: January 1998 to June 2005)

\begin{tabular}{|c|c|c|c|c|}
\hline & Log Level & $\begin{array}{c}\text { First } \\
\text { Difference }\end{array}$ & $\begin{array}{c}\text { Second } \\
\text { Difference }\end{array}$ & $\begin{array}{c}\text { Critical Value } \\
1 /\end{array}$ \\
\hline & \multicolumn{4}{|c|}{ Phillips Perron Test 2/ } \\
\hline CPI & 1.03 & -8.00 & & -2.89 \\
\hline Broad money & 5.95 & -9.21 & & -2.89 \\
\hline Private sector credit & 1.96 & -6.26 & & -2.89 \\
\hline 6-month t-bill & -1.43 & -6.32 & & -2.89 \\
\hline Real GDP & 5.45 & -0.84 & -9.49 & -2.89 \\
\hline LSM index & 4.63 & -5.49 & & -2.89 \\
\hline & -1.57 & -7.56 & & -2.89 \\
\hline \multirow[t]{2}{*}{ Wheat support price } & -0.61 & -9.59 & & -2.89 \\
\hline & \multicolumn{4}{|c|}{ Augmented Dickey-Fuller Test 2/ } \\
\hline CPI & 1.13 & -7.98 & & -2.89 \\
\hline Nonfood & & & & \\
\hline Broad money & 2.90 & -1.84 & -8.40 & -2.89 \\
\hline Private sector credit & 1.51 & -6.25 & & -2.89 \\
\hline 6-month t-bill & -1.90 & -2.83 & -12.12 & -2.89 \\
\hline Real GDP & 1.56 & -0.85 & -9.49 & -2.89 \\
\hline LSM index & 2.87 & -5.47 & & -2.89 \\
\hline NEER & -1.53 & -7.58 & & -2.89 \\
\hline Wheat support price & -0.64 & -9.59 & & -2.89 \\
\hline
\end{tabular}

Source: National authorities; Fund staff calculations

Source: National authorities; Fund staff calculations.
1/ Critical value at the 5 percent level based on MacKinnon (1996). 1/ Critical value at the 5 percel includes intercept.

Table 3. Inflation Determinants-General-to-Specific Modeling 1/ Dependent variable: average annual CPI inflation in percent. Sample: January 1998 to June 2005.

\begin{tabular}{lcrcr}
\hline & M1 & M2 & M3 & M4 \\
\hline Broad money & $3.87 *$ & & $1.46 *$ & \\
Private sector credit & & $0.65 *$ & & $0.28 *$ \\
Real GDP & $-4.52 *$ & $-1.15 *$ & $-2.32 *$ & $-1.67 *$ \\
NEER & $-1.81 *$ & $0.54 *$ & $-0.50 *$ & \\
6-month t-bill 2/ & $0.06 *$ & $0.01 *$ & & \\
Wheat support price & $0.69 *$ & $-0.17 *$ & $0.21 *$ & $0.26 *$ \\
Adjusted R^2 & 0.999 & 1.000 & 0.999 & 0.999 \\
Degrees of freedom & 60 & 35 & 54 & 58 \\
$\quad$ Observations & 78 & 78 & 78 & 78 \\
Regressors & 18 & 43 & 24 & 20 \\
\hline
\end{tabular}

Source: Pakistani authorities and IMF data; authors' calculations.

$1 /$ "*" indicates that all lags of the regressor are jointly significant at the 5 percent level. 2/ Absolute change over the last 12 months in basis points. 
Table 4. Information Criteria to Determine Optimal Lag Length $k$ of VAR 1/

(Endogenous variables: CPI, private sector credit, real GDP, wheat support price all in log levels)

\begin{tabular}{|c|c|c|c|c|c|c|c|c|c|c|c|}
\hline & $\mathrm{k}=2$ & $\mathrm{k}=3$ & $\mathrm{k}=4$ & $\mathrm{k}=5$ & $\mathrm{k}=6$ & $\mathrm{k}=7$ & $\mathrm{k}=8$ & $\mathrm{k}=9$ & $\mathrm{k}=10$ & $\mathrm{k}=11$ & $\mathrm{k}=12$ \\
\hline & \multicolumn{11}{|c|}{ (Endogenous variables: CPI, private sector credit, real GDP, wheat support price all in log levels) } \\
\hline \multicolumn{12}{|l|}{ Aikaiki Information } \\
\hline Criterion & -30.358 & -30.211 & -30.238 & -30.041 & -30.113 & -30.154 & -29.995 & -30.268 & -30.675 & -31.198 & -32.411 \\
\hline Schwarz Criterion & -27.655 & -27.036 & -26.585 & -25.903 & -25.483 & -25.024 & -24.359 & -24.119 & -24.005 & -24.000 & -24.676 \\
\hline & \multicolumn{11}{|c|}{ (Endogenous variables: CPI, private sector credit, wheat support price all in log levels) } \\
\hline \multicolumn{12}{|l|}{ Aikaiki Information } \\
\hline Criterion & -17.539 & -17.511 & -17.446 & -17.289 & -17.220 & -17.193 & -17.036 & -17.008 & -16.851 & -16.783 & -16.673 \\
\hline Schwarz Criterion & -15.681 & -15.385 & -15.049 & -14.617 & -14.268 & -13.958 & -13.514 & -13.195 & -12.742 & -12.374 & -11.960 \\
\hline & \multicolumn{11}{|c|}{ (Endogenous variables: CPI, broad money, real GDP, NEER, wheat support price all in log levels) } \\
\hline \multicolumn{12}{|l|}{ Aikaiki Information } \\
\hline Criterion & -35.808 & -35.645 & -35.770 & -35.646 & -36.210 & -36.184 & -36.313 & -36.489 & -37.234 & -39.316 & -98.016 \\
\hline Schwarz Criterion & -32.148 & -31.251 & -30.633 & -29.755 & -29.554 & -28.752 & -28.095 & -27.473 & -27.408 & -28.669 & -86.535 \\
\hline
\end{tabular}

Source: National authorities; and Fund staff calculations.

1/ VAR includes dummies to control for Islamic and Gregorian calendar effects. 
Table 5. Cointegration Test for the CPI, Private Sector Credit, Wheat Support Price VECM 1/

\begin{tabular}{|c|c|c|c|c|c|}
\hline \multirow{2}{*}{$\begin{array}{l}\text { Number of Coin- } \\
\text { tegrating Vectors }\end{array}$} & \multirow[t]{2}{*}{ Eigenvalue } & \multicolumn{2}{|c|}{ Trace Test } & \multicolumn{2}{|c|}{ Maximum Eigenvalue Test } \\
\hline & & Statistic & $\begin{array}{l}\text { Critical } \\
\text { Value 2/ }\end{array}$ & Statistic & $\begin{array}{l}\text { Critical } \\
\text { Value 2/ }\end{array}$ \\
\hline None & 0.329 & 49.901 & 42.915 & 33.128 & 25.823 \\
\hline At most 1 & 0.109 & 16.773 & 25.872 & 9.594 & 19.387 \\
\hline At most 2 & 0.083 & 7.179 & 12.518 & 7.179 & 12.518 \\
\hline
\end{tabular}

Source: National authorities; and Fund staff calculations.

1/ VECM of lag length 6; includes dummies for Islamic and Gregorian calendar effects.

2/ Based on MacKinnon, Haug, Michaelis (1999) at the five percent level.

Critical values assume no exogenous series in the VECM. 